\title{
PENGARUH SUBSTITUSI TEPUNG PISANG PADA PEMBUATAN BROWNIES TERHADAP SIFAT KIMIA DAN PENERIMAAN ORGANOLEPTIK
}

\section{The Effects of Banana Flour Substitution on The Making of Browniez To The Chemical Properties and Organoleptic Acceptance}

Silfia

Balai Riset dan Standardisasi Industri Padang

JI. Raya LIK Ulu Gadut No. 23 Telp. (0751) 72201 Fax.(0751) 71320 Padang 25164

e-mail: silfiabintiarsul@yahoo.com

Diterima: 22 September 2012, Revisi akhir: 20 November 2012

\section{ABSTRAK}

Pisang kepok (Musa paradisiacal $L$ ) merupakan pisang yang biasanya dikonsumsi setelah diolah terlebih dahulu. Daging buahnya memiliki kandungan padatan yang cukup tinggi sehingga sangat cocok untuk dijadikan tepung pisang. Tepung pisang diperoleh dari daging buah pisang melalui proses pengeringan dan penggilingan. Manfaat diolah menjadi tepung pisang adalah agar lebih tahan lama, lebih mudah dalam pengemasan dan pengangkutan, lebih praktis untuk diversifikasi produk olahan, memberikan nilai tambah buah pisang, dan menciptakan peluang usaha pengembangan agroindustri pedesaan dan mengurangi penggunaan pemakaian terigu. Penelitian pembuatan brownies pisang dilakukan dengan perlakuan perbandingan tepung pisang dengan tepung terigu. Persentasi tepung pisang yang digunakan adalah 100\%, 75\%, 50\%, 25\%, dan kontrol. Produk kemudian dianalisis kadar serat kasar, air, protein, dan uji organoleptik terhadap rasa, aroma, dan tekstur. Hasil penelitian menunjukkan bahwa pembuatan brownies pisang memberikan hasil yang optimal pada perlakuan penggunaan tepung pisang $75 \%$ dengan kadar serat kasar $1.88 \%$, kadar air $38.01 \%$, protein $12.09 \%$, tekstur, rasa, dan aroma disukai panelis.

\section{Kata Kunci: Pisang, brownies, tepung pisang}

\begin{abstract}
Kepok banana (Musa paradisiaca L) is a banana which is usually consumed after being processed first. The banana flesh has a high solid content so that it is very suitable to be made banana flour. Banana flour is obtained from banana fruit flesh through a process of drying and milling. The benefits of banana flours will make it more durable, easier in packing and transportation, more practical for diversifying processed products, to provide added value of banana, and to create business opportunities for the rural agroindustry development. Thus the study was conducted to compare the banana flour with wheat flour. The concentration of banana flour used were $100 \%, 75 \%, 50 \%, 25 \%$, and $0 \%$ (control). Products were then analyzed for the crude fiber content, water content, protein, and organoleptic tests were done for taste, aroma, and texture. The results showed that the banana browniez provide the optimum result in treatment when $75 \%$ of banana flour was used resulting crude fiber content $1.88 \%$, water content $38.01 \%$, protein content $12.9 \%$, texture, taste and aroma were preferred by the panelists.
\end{abstract}

Key words : Banana, browniez, banana flour

\section{PENDAHULUAN}

Pisang (Musa paradisiaca) sebagai
salah satu tanaman buah-buahan
mempunyai potensi besar diolah menjadi
tepung sebagai substitusi tepung terigu.

Tepung pisang merupakan produk antara yang cukup prospektif dalam pengembangan sumber pangan lokal. Buah pisang cukup sesuai untuk diproses menjadi tepung mengingat bahwa komponen utama penyusunnya adalah 
karbohidrat (17,2\%-38\%). Produksi tepung pisang nasional mencapai 4.384.384 ton (BPS, 2010) dengan nilai ekonomi sebesar Rp 6.5 triliun. Produksi tersebut sebagian besar dipanen dari pertanaman kebun rakyat seluas 269.000 ha. Karena keterbatasan teknologi yang dimiliki, hasil panen hanya dapat dipasarkan dalam bentuk tandan buah segar. Selain keuntungan yang tidak terlalu besar, terkadang petani juga menghadapi kendala dalam penanganan pasca panen buah pisang, terutama selama masa penyimpanan dan pengangkutan. Tidak sedikit dari hasil panen tersebut mengalami cacat fisiologis (busuk, penyet, terpotong, dan lain-lain) yang akhirnya menurunkan kuantitas dan kualitas buah pisang tersebut. (Anonim, 2008).

Semua bagian pisang memiliki banyak kegunaan. Buah pisang yang masak mengandung vitamin $A$, vitamin $C$, vitamin B komplek, vitamin B6, soronium yang aktif sebagai neurotransmitter dalam kelancaran fungsi otak, kalsium, fosfor (Anonim, 2008). sedangkan buah yang masih hijau biasanya dicuci dengan air mendidih, dikupas, diiris, dijemur, ditumbuk dan diayak sampai berbentuk tepung seperti yang biasa dipakai untuk membuat roti dan bubur. Tepung pisang sangat baik untuk penyembuhan sejumlah penyakit yang disebabkan gastrointestinal (radang usus/lambung), misalnya diare, disentri, dan pencernaan yang terganggu. Disamping itu tepung pisang merupakan salah satu alternatif produk setengah jadi yang dianjurkan karena lebih tahan disimpan, mudah dicampur (dibuat tepung komposit) diperkaya zat gizi (difortifikasi), dibentuk dan lebih cepat dimasak sesuai dengan tuntutan kehidupan modern yang serba praktis (Widowati, dan Darmajati 2001). Selain itu diolah menjadi biskuit, brownies pisang, dan lain-lain.

Brownies merupakan salah satu jenis cake yang berwarna cokelat kehitaman. Brownies ada dua macam yaitu brownies kukus dan brownies oven sama seperti cake. Tekstur brownies lebih padat dari pada cake karena brownies tidak membutuhkan pengembangan yang tinggi (Sulistiyo, 2006).

Tepung yang biasa digunakan dalam pembuatan brownies, adalah tepung terigu.
Konsumsi tepung terigu secara nasional terus meningkat, berdasarkan catatan Asosiasi Produsen Tepung Terigu Indonesia, konsumsi terigu di dalam negeri mencapai 1,22 juta ton pada kuartal I-2012, naik $5,61 \%$ dibandingkan periode sama tahun 2011 yang tercatat 1,15 juta ton.

Berdasarkan hal itu maka dilakukan Penelitian pengaruh substitusi tepung pisang pada pembuatan brownies terhadap sifat kimia dan penerimaan organoleptik dengan tujuan untuk mengurangi pemakaian terigu, dan penggunaan tepung pisang sebagai bahan baku pembuatan produk dalam industri pangan, sebagai upaya dalam menurunkan biaya produksi dan mengangkat nilai jual pisang. Tepung pisang mempunyai rasa dan bau yang khas sehingga dapat digunakan pada pengolahan berbagai jenis makanan yang berbahan baku tepung terigu. Substitusi dapat dilakukan untuk menggantikan sebagian atau seluruh tepung terigu (Widowati, 2001).

\section{METODOLOGI PENELITIAN}

\section{Bahan}

Bahan baku yang digunakan dalam penelitian ini adalah pisang yang sudah tua tapi belum masak, bahan untuk proses seperti tepung terigu, telur, gula, mentega, vanile, garam, tepung cokelat dan kemasan serta bahan kimia untuk analisis kadar serat kasar, kadar air dan protein.

Alat

Peralatan yang digunakan dalam penelitian ini terdiri dari kukusan stainless, pisau, talenan, ketam pengiris, kompor, sendok pengaduk, tempat peniris, sendok penjepit, oven, waskom dan sealer serta peralatan untuk pengujian serat kasar, protein, air.

\section{Rancangan Penelitian}

Penelitian dilakukan menggunakan Rancangan Acak Lengkap (RAL) secara faktorial yaitu Perbandingan tepung pisang dengan tepung terigu: $100 \%$ tepung pisang (A), 75\% tepung pisang (B), 50\% tepung 
pisang (C), 25\% tepung pisang (D), dan kontrol (E).

\section{Pelaksanaan}

Diagram alir pembuatan brownies pisang adalah seperti pada Gambar 1.

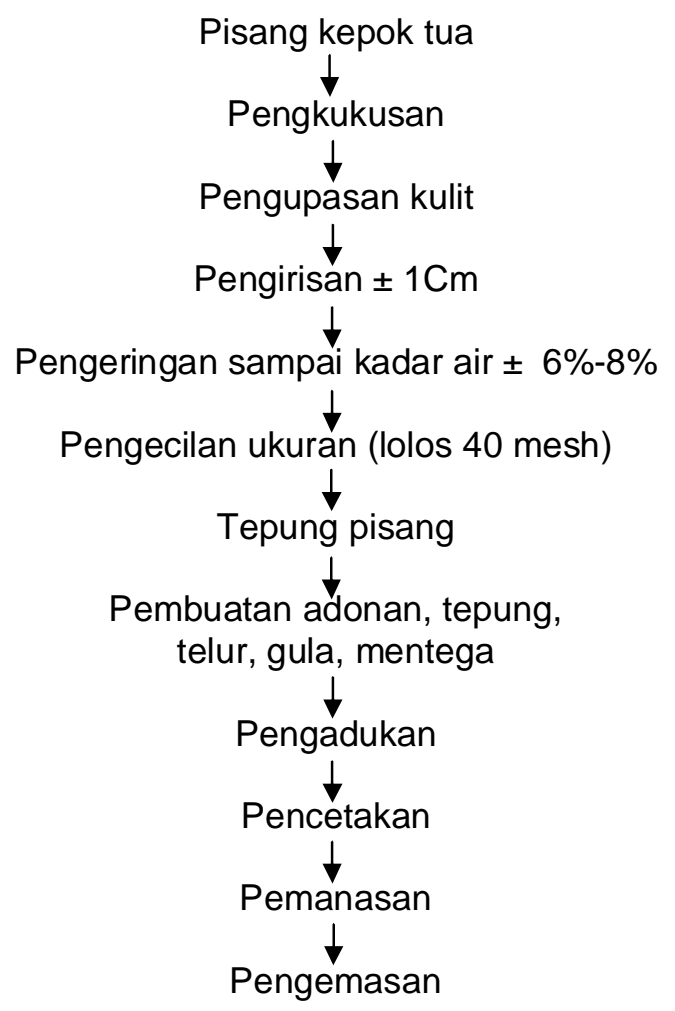

Gambar 1. Diagram alir pembuatan brownies pisang

Jenis pisang yang digunakan adalah pisang kepok, yang sudah tua tetapi belum masak. Pisang dicuci dengan air mengalir, selanjutnya pisang direbus selama-10-15 menit. Pisang diiris tipis melintang dengan ketebalan 1-2 mm, lalu dikeringkan pada 60-75 ${ }^{0} \mathrm{C}$ sampai kering. Selanjutnya digiling dan diayak. Tepung siap untuk diolah menjadi produk brownies pisang.

\section{Analisis.}

Analisis kimia dilakukan terhadap brownies pisang meliputi kadar air, serat kasar dan protein. Untuk uji organoleptik menggunakan skala hedonik skala 1-5 dengan penilaian tidak suka, kurang suka, biasa, suka dan sangat suka.

\section{HASIL DAN PEMBAHASAN}

\section{Serat kasar}

Hasil analisis kadar serat kasar brownies pisang seperti terlihat pada Gambar 2.

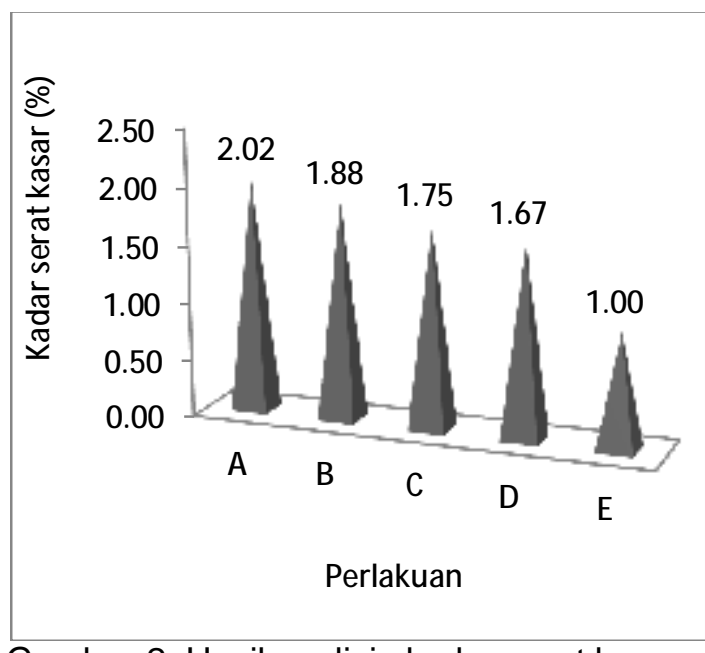

Gambar 2. Hasil analisis kadar serat kasar brownies pisang

Hasil analisis serat kasar brownies pisang seperti terlihat pada Gambar 2, dimana serat kasar perlakuan $100 \%$ tepung pisang adalah $2.02 \%$ lebih tinggi dari kadar serat kasar brownies pisang pada perlakuan $100 \%$ tepung terigu yakni $1 \%$. Semakin banyak tepung pisang yang ditambahkan maka semakin besar kadar serat kasar brownies pisang. Kadar serat pisang lebih tinggi daripada kadar serat terigu, sehingga semakin berkurang kadar tepung pisang maka kadar serat brownies semakin rendah.

Menurut Anonim (2005), tingginya kadar serat pada tepung pisang disebabkan karena sisa dari komponen kimia dalam bahan pisang seperti selulosa dan lignin, serta selulosa jenis karbohidrat yang ada dalam tepung pisang mempunyai struktur polimer homolog beta glukosa dan polisakarida yang mempunyai rantai sangat panjang sehingga saat degradasi kimia tidak semua rantai polimer tersebut dapat terputus dan lignin sangat tahan terhadap setiap degradasi kimia, termasuk degradasi enzimatik yang terukur saat pengujian. Sementara sisa dari komponen kimia yang ada dalam tepung terigu seperti pektin dan 
gum mudah terdegradasi. Kadar serat kasar tepung pisang 1.96\%-2.51\% (Antarlina et al,2004) lebih tinggi dari serat kasar tepung terigu 1\% (Makfoeld Djarir, 1982).

Manfaat serat dalam pisang sangat efektif untuk mencegah sembelit. Serat ini mampu menyerap air dalam saluran pencernaan, sehingga feses menjadi lunak, tekanan dalam usus besar akan berkurang, dan akhirnya memperlancar buang air besar. Serat dalam pisang juga mampu meningkatkan pembuangan kolesterol. Jika kolesterol darah berkurang, penyakit jantung koroner, aterosklerosis, stroke, hipertensi, dan berbagai penyakit degeneratif lainnya dapat dicegah (Farhan,2012).

\section{Kadar air}

Hasil analisis kadar air brownies pisang seperti terlihat pada Gambar 3, yang ber kisar antara 37.02\%-39.45\%. Menurut Herman (1991), pangan yang mempunyai kadar air 15\%-40\% digolongkan dalam pangan semi basah. Kadar air perlakuan $100 \%$ tepung pisang paling rendah, sedangkan perlakuan kontrol paling tinggi dibandingkan perlakuan lainnya. Pada Gambar 3 dapat dilihat bahwa semakin tinggi persentase tepung pisang yang ditambahkan, maka semakin rendah kadar air brownies pisang yang dihasilkan. Hal ini karena kandungan pati yang tinggi pada tepung pisang berpengaruh terhadap penurunan kadar air karena kemampuan daya ikat molekul air pada pati pisang lebih rendah dibandingkan dengan daya ikat molekul air pada pati tepung terigu sehingga akan terjadi pengurangan kadar air lebih cepat dari tepung pisang pada saat pengeringan dibandingkan dengan produk dari tepung terigu (Fauzi 2006).

Selanjutnya menurut Nita (2012), secara mikroskopik daya ikat molekul air pada pati pisang rendah karena suhu gelatinisasi tepung pisang lebih tinggi $\left(68.8^{\circ} \mathrm{C}-77.5^{\circ} \mathrm{C}\right)$ dibandingkan dengan suhu gelatinisasi tepung terigu $\left(53^{\circ} \mathrm{C}-63^{\circ} \mathrm{C}\right)$ dan ukuran granula pati tepung pisang $60 \mu \mathrm{m}-$ $105 \mu \mathrm{m}$ lebih besar dari ukuran granula pati tepung terigu $2 \mu \mathrm{m}-35 \mu \mathrm{m}$. Semakin besar ukuran granula pati, maka daya ikat molekul air dalam produk menjadi rendah, sehingga lebih mudah melepaskan molekul air saat pemanasan produk. Menurut Apriantono (2002), bila pati dipanaskan, maka granula-granula pati membengkak, pecah, dan pati tergelatinisasi sehingga lebih mudah melepaskan molekul air.

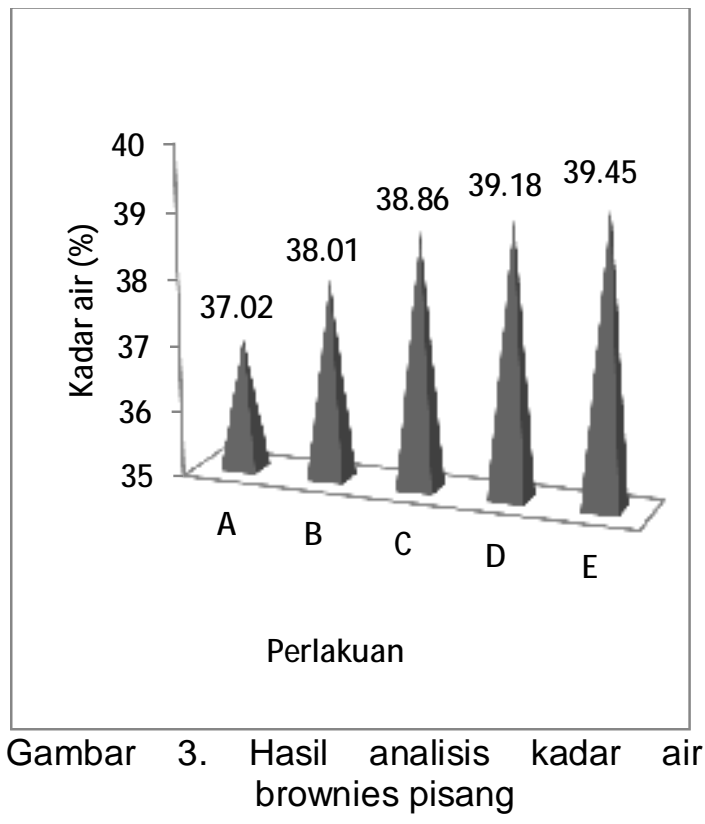

Tingginya kadar air pada brownies menyebabkan brownies memiliki umur simpan yang tidak terlalu lama. Menurut Sulistiyo (2006), umur simpan produk ini hanya mencapai 3 hari. Produk ini mengalami penurunan kadar air setiap harinya sehingga menyebabkan teksturnya berubah. Kekerasan produk meningkat setiap hari dengan adanya penurunan kadar air. Selain itu, produk ini mulai ditumbuhi mikroba pada hari keempat.

\section{Kadar Protein}

Hasil analisis kadar protein brownies pisang seperti terlihat pada Gambar 4. Kadar protein brownies pisang berkisar antara 11.87\%-12.63\%. Perlakuan 100\% penggunaan tepung pisang menghasilkan kadar protein paling rendah (11.87\%) dibandingkan dengan perlakuan lainnya. Kadar protein yang paling tinggi pada perlakuan $100 \%$ tepung terigu (E) yaitu $12.63 \%$. Kadar protein yang tinggi pada brownies dipengaruhi oleh kadar protein terigu yang lebih tinggi. 


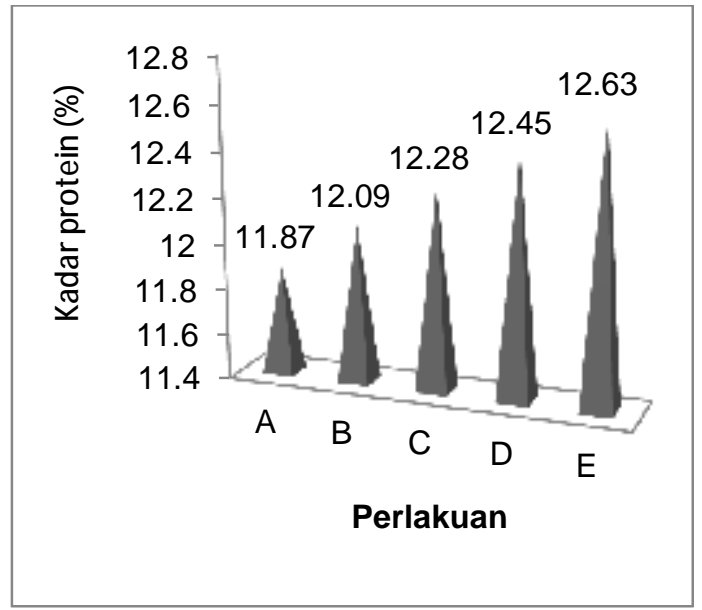

Gambar 4. Hasil analisis kadar protein brownies pisang

Menurut Fajri (2012), perbedaan kadar protein pada setiap perlakuan, disebabkan oleh karena adanya gugus asam amino protein yang berbeda pada bahan produk, tepung pisang (kadar protein $3.36 \%-4.12 \%$ ), tepung terigu rendah kadar protein 8\%-9\% (Sukendar, 2011) dan telur (kadar protein 6\%) yang berbeda diolah bersama-sama, maka kekurangan asam amino dari satu protein dapat ditutupi oleh asam-amino sejenis yang berlebihan pada protein lain. Dua atau tiga protein tersebut saling mendukung sehingga dihitung sebagai protein. Kandungan protein yang dihasilkan lebih tinggi dibandingkan dengan kadar protein brownies yang diperoleh (Sulistiyo, 2006) yaitu sebesar $5,54 \%$.

\section{Uji Organoleptik}

\section{Rasa}

Berdasarkan uji organoleptik yang dilakukan panelis diperoleh hasil yang berbeda nyata terhadap nilai rasa brownies pisang. Nilai rasa hasil uji organoleptik brownies pisang yang disubsitusi dengan tepung pisang berkisar antara (4.35 - 4.0) disukai panelis seperti terlihat pada Gambar 5.

Semakin tinggi persentasi tepung pisang yang ditambahkan semakin disukai oleh panelis. Menurut Fajri (2012), tepung pisang mempunyai rasa yang khas dan istimewa sehingga dapat digunakan sebagai bahan campuran dalam pembuatan aneka jenis makanan. Menurut pendapat Qazuini (1984), citarasa makanan dipengaruhi oleh beberapa faktor antara lain bahan penyusunnya yaitu karbohidrat $(21,0 \mathrm{~g}-33,6, \mathrm{~g})$, protein $1,4 \mathrm{~g}$ dan lemak 0,2 g per $100 \mathrm{~g}$ daging buah pisang. Terbentuknya rasa manis yang khas pada tepung pisang berasal sebagian dari karbohidrat yang berubah menjadi tiga gula yaitu sukrosa, fruktosa, dan glukosa, yang terjadi pada pengukusan buah.

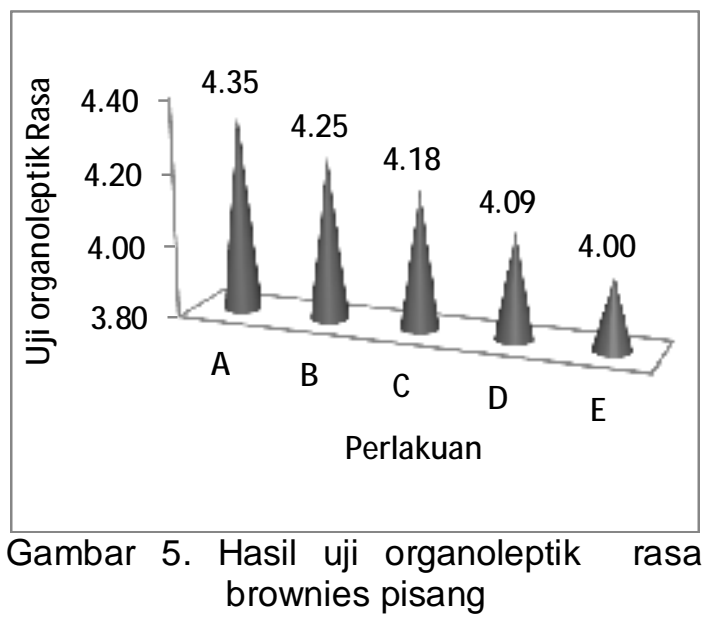

Selanjutnya Charles dkk (2002), mengatakan bahwa rasa merupakan perbedaan genetik dalam sub-unit reseptor asam amino yang berasal dari brownies pisang yang dapat mempengaruhi rasa. Perbedaan-perbedaan seperti ini dapat membantu menerangkan adanya variasi individual dalam rasa, sehingga nilai rasa produk akan bervariasi.

\section{Tekstur}

Berdasarkan uji organoleptik terhadap tekstur brownies pisang yang di subsitusi dengan tepung pisang memberikan hasil berbeda tidak nyata terhadap tekstur. Nilai tekstur berkisar 3.8- 4.12 (disukai) seperti terlihat pada Gambar 6 .

Semakin banyak tepung pisang yang ditambahkan maka tekstur brownies pisang semakin empuk serta disukai oleh panelis, menurut Nita (2012), secara mikroskopik adanya gugus hidroksil bebas akan menyerap air, sehingga terjadi pembengkakan granula pati. Dengan demikian, semakin banyak jumlah gugus 
hidroksil dari molekul pati tepung pisang maka semakin tinggi kemampuannya menyerap air, sehingga saat dilakukan proses pengeringan daya ikat molekul air pada produk rendah sehingga tekstur produk menjadi lebih empuk.

Selanjutnya menurut Suganda (2006), empuknya brownies pisang disebabkan oleh kandungan pati pada pisang yang terdiri dari amilosa yang mempunyai struktur lurus dengan ikatan -(1,4)-Dglukosidik dan amilopektin yang mempunyai struktur bercabang dengan ikatan -(1,6)-D-glukosidik, semakin tinggi kadungan amilosa pada tepung pisang maka akan meningkatkan tingkat kekompakkan pada produk. Disamping itu lesitin pada kuning telur merupakan pengemulsi yang baik, dan dapat mempercepat hidrasi air pada adonan brownies, sehingga tekstur brownies menjadi lebih empuk (Eka, 2012).

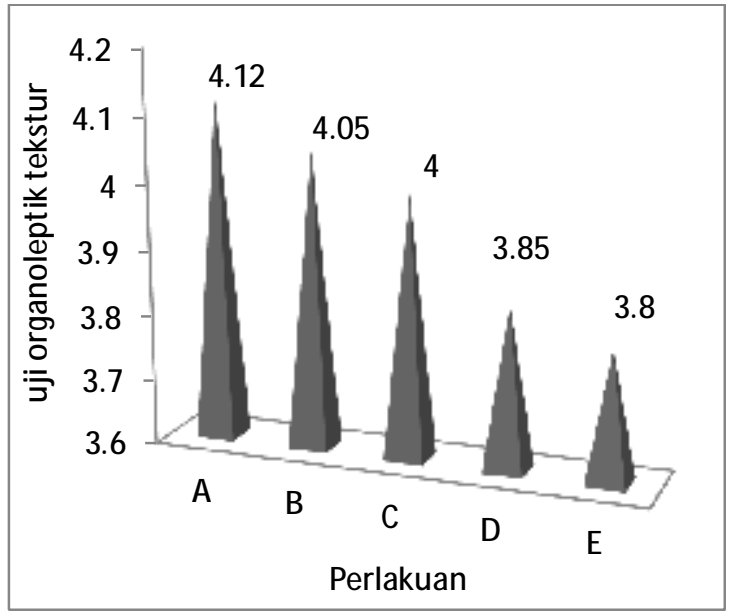

Gambar 6 Hasil uji organoleptik tekstur Brownies pisang.

\section{Aroma}

Berdasarkan uji organoleptik yang dilakukan panelis diperoleh hasil yang berbeda nyata terhadap nilai aroma brownies pisang. Nilai aroma berkisar antara 3.91 - 4.15 (suka) seperti Gambar 7.

Dari Gambar 7 terlihat bahwa aroma untuk semua perlakuan disukai oleh panelis, karena adanya kandungan pati yang terdegradasi waktu proses pengeringan adonan brownies pisang. Saat pengeringan kandungan pati tepung pisang terdegradasi, sehingga terjadi perubahan yang ekstensif dengan eliminasi molekul air dan fragmentasi molekul gula dimana terjadi pemutusan ikatan karbon yang akan menghasilkan senyawa karbonil dan senyawa volatil sehingga menimbulkan aroma yang khas dari brownies pisang (Suhartono, 2011).

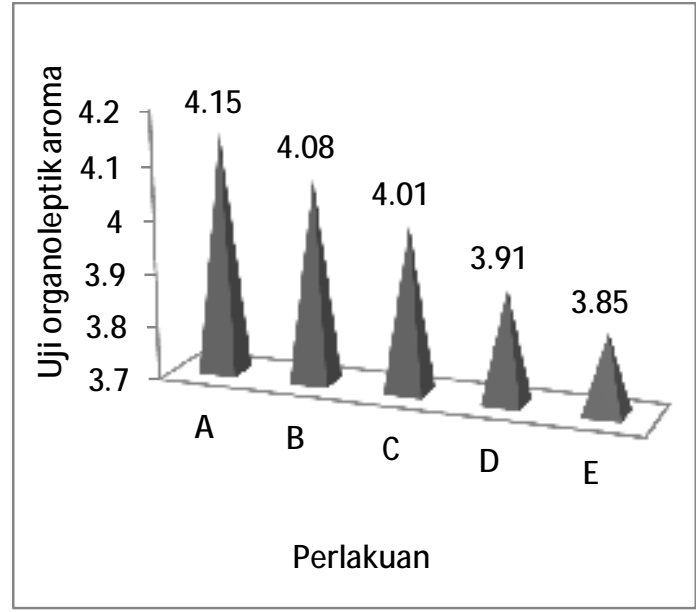

Gambar 7. Hasil uji organoleptik aroma brownies pisang

Selanjutnya De Man (2003), mengatakan bahwa senyawa volatil adalah berbentuk senyawa yang mudah menguap dimana molekul komponen tersebut menyentuh lebih kurang 16 juta jenis aroma dan ini lebih kecil dibandingkan dengan makhluk lain. Aroma tidak tergantung pada penglihatan, pendengaran dan sentuhan Menurut Wijaya (2009), aroma adalah sensasi dari senyawa volatil yang diterima oleh rongga hidung.

\section{KESIMPULAN DAN SARAN}

\section{Kesimpulan}

Dari penelitian pengaruh substitusi tepung pisang pada pembuatan brownies terhadap sifat kimia dan penerimaan organoleptik yang telah dilakukan dapat disimpulkan bahwa :

1. Tepung pisang dapat mensubstitusi penggunaan tepung terigu pada pembuatan brownies pisang sampai $75 \%$. 
2. Perlakuan terbaik adalah pada perlakuan dengan pemakaian tepung pisang $75 \%$ memberikan kadar serat kasar $1.88 \%$, kadar air $10.85 \%$, protein $12.09 \%$, tekstur, rasa dan aroma disukai oleh konsumen.

\section{Saran}

Dari penelitian ini diharapkan agar masyarakat industri dan petani pisang dapat menerapkan teknologi pembuatan brownies pisang pada pembinaan industri kecil brownies dalam pemanfaatan pisang sehingga pemakaian tepung terigu dapat dikurangi dalam pembuatan brownies.

\section{DAFTAR PUSTAKA}

Anonim, 2005. Kandungan Pisang. http:www.ebookpangan.com diakses tanggal 13 Januari 2012.

Anonim, 2005. Tepung Pisang Pengganti Terigu. diakses pada selasa, 17 April 2012.

Anonim, 2008. Gizi Pisang. http//id.wikipedia.org/wiki/pisang. Diakses tanggal 13 Januari 2012.

Anonim, 2009. Hasil analisis tepung pisang Direktorat jenderal Pengolahan dan pemasaran hasil pertaniaan Departemen Pertanian Jakarta. Diakses 13 Januari 2012.

Anonim, 2012. Tepung Pisang dan Olahannya. IPB Bogor. w.w.w. warintek.ristek go..id. diakses pada 13 Januari 2012.

Apriantono, A., 2002. Pengaruh Pengolahan Terhadap Nilai Gizi dan Keamanan Pangan. Makalah seminar Kharisma Online. Dunia Maya.

Antarlina, S.S., Y. Rina,S., Umar dan Rukayah, 2004. Pengolahan buah pisang dalam mendukung Agroindustri di Kalimantan. Dalam Prosiding Seminar Nasional Klinik Teknologi Pertanian Sebagai Basis Pertumbuhan Usaha agribisnis Menuju Petani
Nelayan Mandiri. Puslitbang Sosek Pertanian. Diakses 7 Februari 2012.

Herman, AS., 1991. Pengetahuan Bahan dan Produk Industri kecil Pengolahan Pangan.

Eka, A., 2012. Proses Pembuatan Mie Pisang Akses 7 februari 2012.

Badan Pusat Statistik dan Bappeda Propinsi Sumatera Barat, 2010. Sumatera Barat Dalam Angka dan Pusat Statistik Propinsi Sumatera Barat. Padang.

Charles, S. Zuker. 2002 . Nicholas J.P. Identifikasi reseptor rasa asam amino Nature. Diakses 17 April 2012.

De Man, John M. 2003. Kimia makanan. Penerbit ITB. Bandung.

Fajri, M. 2012, Aplikasi Protein dalam Pengolahan Makanan. Teknologi Hasil Pertanian, Fakultas Pertanian Universitas Jambi. Diakses 4 Januari 2012.

Farhan. 2012. Manfaat Pisang Mas. Diakses 13 Januari 2012.

Fauzi, M. 2006. Analisa Pangan dan Hasil Pertanian Handout. Jember: FTP UNEJ.

Kendar, I. 2011. Jenis Terigu dan Kegunaannya. Multiply. com/journal/ /Jenis-Terigu-dan-kegunaannya. Diakses 04 Januari 2012.

Djarir, M. 1982. Deskripsi Pengolahan Hasil Nabati. Yogyakarta. : Agritech.

Matz, S., A. 1992. Bakery Technology and Engineering. 3rd Ed. Pantech International Inc., Texas. Diakses 04 Januari 2012

Nita, M. 2012. Karateristik granula pati dari berbagai-macam-sumber-Pati blog.ub.ac.id. Diakses 04 Januari 2012. 
Potter, N.N. 1973. Food Science. The Avipubl.co.inc. Wesport Connecticut.

Qazuini, M. 1984. Pengujian inderawi Bahan Makanan dan Minuman. Universitas Mataram. Diakses 04 Januari 2012.

Singh, A., Chan, J., Chern, J.J., Choi, K.W. 2005. Genetic interaction of Lobe with its modifiers in dorsoventral patterning and growth of the Drosophila eye.

Suganda. 2006. Pengaruh Konsentrasi dan Lama Perendaman dalam Larutan Natrium Bikarbonat Terhadap Karakteristik Keripik Pisang, UNPAS, Bandung.

Suhartono, A. 2011. Studi pembuatan roti dengan subsitusi tepung pisang kepok Fakultas Pertanian Universitas Hasanuddin Makasar.
Sulistiyo, CN. 2006. Pengembangan Brownies Kukus Tepung Ubi Jalar di PT. Fits Mandiri Bogor. Skripsi. Fakultas Teknologi Pertanian. Institut Pertanian Bogor. IPB.

Widowati, S dan D.S. Darmadjati. 2001. Menggali Sumberdaya Pangan Lokal Dalam rangka Ketahanan Pangan . Majalah PANGAN no. 36/x/jan/2001. BULOG, Jakarta.

Wijaya, $\quad$ 2009. Foodreview Foodreview Indonesia Vol. IV.

Winarno, F. G. 2002. Kimia Pangan dan Gizi, P.T. Gramedia Utama, Jakarta

Winarno, F.G. 2004. Kima Pangan dan Gizi. PT.Gramedia Utama, Jakarta 